\title{
Trends in Factor Price Elasticities Adding Energy to Capital and Labor in the US Economy
}

\author{
HENRY THOMPSON \\ Auburn University*
}

\begin{abstract}
This paper estimates trends in factor price elasticities adding energy Btu input to fixed capital assets and the labor force in annual US data from 1949 to 2013. Second order effects improve estimates of the production function in log differences. The unrestricted estimates test for concavity and constant returns to scale. Adding energy input reduces the apparent productivity of labor and reveals strong capital-labor factor price elasticities with pronounced trends. Energy and labor trend to become weak complements. These trends offer insight into recent economic history and keys to predicting the future as well.
\end{abstract}

Keywords: energy input; factor productivity; factor price elasticity

JEL Classifications: D58, E17, Q43

The present paper estimates trends in factor price elasticities adding energy Btu input to fixed capital assets and the labor force in estimated production function for annual US data from 1949 to 2013. The log difference stationary series lead to reliable difference equation estimates with second order effects that improve fit and increase the range of factor price elasticities. Adding energy input increases explanatory power by half and reveals stronger trends in factor price elasticities involving capital and labor. The marginal rates of substitution of energy for both capital and labor trend to become very elastic after the energy crises while the marginal rate of substitution of labor for capital trends to become more inelastic. Aside from these empirical reasons, adding energy input is motivated by its role in refining, operating machinery and equipment, transport, indoor climate control, lighting, and electronics.

Log linear estimates with the present data lead to weak cross price substitutes as in the applied production literature. The second order effects increase the range of factor price elasticities to strong substitutes and weak complements. A structural break for the energy crisis proves significant. The constant terms in the log difference estimates provide tests of the null

\footnotetext{
* Thanks go to Panagiotis Chronis and Dimitris Malliaropoulos for comments on a presentation at the Bank of Greece. Referees and editor of this journal also provided constructive suggestions that improved the paper. Department of Economics, 125 Miller Hall, Auburn University, AL 36849, 334844-2910, henry.thompson@auburn.edu

(C) 2019 Henry Thompson. Licensed under the Creative Commons Attribution - Noncommercial 3.0 Licence (http://creativecommons.org/licenses/by-nc/3.0/. Available at http://rofea.org.
} 
hypothesis of an unexplained output trend, and the estimated parameters provide tests of concavity and constant returns to scale.

Trends in factor price elasticities are derived based on cost minimizing behavior. The own labor elasticity trends to become elastic, much more when energy input is added. The capitalwage cross price elasticity has an accelerating trend becoming more elastic especially adding energy input. Cross price elasticities between capital and energy are weak but trending upward suggesting the issue of capital-energy complements in the literature is becoming less critical. An unexpected property is that labor trends to become a weak complement with energy suggesting rising energy prices would hurt labor. The present trends in factor price elasticities offer insight into recent economic history and provide hints for future policy.

Section 1 briefly reviews the theory of factor price elasticities based on cost minimizing behavior. Section 2 reviews the applied literature that includes energy input with capital and labor. Section 3 analyzes properties of the present time series and discusses derived trends in average products and factor intensities. Section 4 presents estimates of log linear production functions with and without energy input. Section 5 examines the influence of second order effects in the estimated production functions. Section 6 compares trends in factor price elasticities across different specifications. The Conclusion discusses some of the implications of the estimated trends in factor price elasticities.

\section{Cost Minimization and Factor Price Elasticities}

The fundamental theory of input price elasticities based on cost minimization is developed in Allen (1938), Ferguson and Pfouts (1962), Berndt and Christensen (1973), and Takayama (1993). Energy input is explicitly included by Field and Grebenstein (1980) and Denny, Fuss, and Waverman (1981). The theory starts with the Lagrangian constrained cost minimization including the production function $\mathrm{Y}(\mathrm{K}, \mathrm{L}, \mathrm{E})$ with capital $\mathrm{K}$, labor L, and energy $\mathrm{E}$ inputs paid $r, w$, and e. Cost is minimized to produce output $Y$ with input levels selected given input prices leading to the first order conditions,

$$
\begin{gathered}
\Gamma=\mathrm{rK}+\mathrm{wL}+\mathrm{eE} \gamma(\mathrm{Y}-\mathrm{Y}(\mathrm{K}, \mathrm{L}, \mathrm{E})) \\
\Gamma \gamma=\mathrm{Y}-\mathrm{Y}(\mathrm{K}, \mathrm{L}, \mathrm{E})=0 \\
\Gamma_{\mathrm{K}}=\mathrm{r}-\gamma \mathrm{Y}_{\mathrm{K}}=\Gamma_{\mathrm{L}}=\mathrm{w}-\gamma \mathrm{Y}_{\mathrm{L}}=\Gamma_{\mathrm{E}}=\mathrm{e}-\gamma \mathrm{Y}_{\mathrm{E}}=0
\end{gathered}
$$

The present focus is on unit output $Y=1$ as the basis of factor price elasticities. Competitive pricing implies marginal cost $\gamma=1$ on the unit isoquant where $Y=1$ and $d Y=Y_{K} d K+$ $Y_{L} d L+Y_{E} d E=0$. Slopes of the unit isoquant are the three marginal rates of substitution, $\mathrm{dK} / \mathrm{dL}=-\mathrm{Y}_{\mathrm{L}} / \mathrm{Y}_{\mathrm{K}}, \mathrm{dK} / \mathrm{dE}=-\mathrm{Y}_{\mathrm{L}} / \mathrm{Y}_{\mathrm{K}}$, and $\mathrm{dL} / \mathrm{dE}=-\mathrm{Y}_{\mathrm{E}} / \mathrm{Y}_{\mathrm{L}}$. The total differential of cost $c=r K+w L+e E$ reduces to $d c=K d r+L d w+$ Ede due to cost minimization. Constant 


\section{THOMPSON Trends in Factor Price Elasticities}

returns to scale CRS imply the cost function is homogenous of degree one with $\mathrm{c}=\Sigma \mathrm{f}(\partial \mathrm{c} / \partial \mathrm{f})$ where $f$ represents factor prices $r, w$, and e. Shephard's lemma $\partial c / \partial f=F$ where F represents an input level follows from cost minimization.

The present specification adds second order effects to the log linear specification,

$$
\ln Y=a_{1} \ln K+a_{2} \ln L+a_{3} \ln E+a_{4} \ln K \ln L+a_{5} \ln K \ln E+a_{6} \ln L \ln E .
$$

The three cross effects are tested first separately, then in pairs, and finally together as in (2). The difference stationary series lead to estimates in differences,

$$
\begin{gathered}
\Delta \ln Y=a_{0}+a_{1} \Delta \ln K+a_{2} \Delta \ln L+a_{3} \Delta \ln E+a_{4} \Delta(\ln K \ln L)+a_{5} \Delta(\ln K \ln E)+ \\
a_{6} \Delta(\ln L \ln E)+\varepsilon .
\end{gathered}
$$

Estimates of the log linear specification have residual correlation while the second order effects lead to reliable time series properties. A structural break for the energy crisis improves the estimates.

First order derivatives of (2) are $\varphi_{\mathrm{K}} \equiv \frac{\partial \ln \mathrm{Y}}{\partial \ln \mathrm{K}}=\mathrm{a}_{1}+\mathrm{a}_{4} \ln \mathrm{L}+\mathrm{a}_{5} \ln \mathrm{L}, \varphi_{\mathrm{L}}=\mathrm{a}_{2}+\mathrm{a}_{4} \ln \mathrm{K}+$ $a_{6} \ln E$, and $\varphi_{E}=a_{3}+a_{5} \ln K+a_{6} \ln L$. The marginal effects for capital with $\varphi_{K}=Y_{K} K / Y$ lead to marginal product $\mathrm{Y}_{\mathrm{K}}=\frac{\varphi_{\mathrm{K}} \mathrm{Y}}{\mathrm{K}}$ and the second order effects $\mathrm{Y}_{\mathrm{KK}}=\phi_{\mathrm{K}}\left(\phi_{\mathrm{K}}-1\right) \mathrm{Y} / \mathrm{K}^{2}, \mathrm{Y}_{\mathrm{KL}}=$ $\mathrm{Y}_{\mathrm{LK}}=\left(\mathrm{a}_{4}+\phi_{\mathrm{K}} \phi_{\mathrm{L}}\right) \mathrm{Y} / \mathrm{KL}$, and $\mathrm{Y}_{\mathrm{KE}}=\mathrm{Y}_{\mathrm{EK}}=\left(\mathrm{a}_{5}+\phi_{\mathrm{K}} \phi_{\mathrm{E}}\right) \mathrm{Y} / \mathrm{KE}$. The $\varphi_{\mathrm{i}}$ would be factor shares $\theta_{\mathrm{i}}$ assuming factors are paid marginal products. Second order effects introduce flexible factor shares while the $\log$ linear specification implies $\varphi_{\mathrm{i}}=\mathrm{a}_{\mathrm{i}}$. Second order effects can reveal elastic substitutes and complements while log linear production is limited to weak or moderate substitutes.

The total differential of the first order condition $r=\gamma Y_{K}$ in (1) is $d r=Y_{K} d \gamma+\gamma d Y_{K}=$ $\mathrm{Y}_{\mathrm{K}} \mathrm{d} \gamma+\gamma\left(\mathrm{Y}_{\mathrm{KK}} \mathrm{dK}+\mathrm{Y}_{\mathrm{KL}} \mathrm{dL}+\mathrm{Y}_{\mathrm{KE}} \mathrm{dE}\right)$ with similar expressions for $\mathrm{dw}$ and de. Including the differential of output $d Y=0$ results in the familiar bordered Hessian system for cost minimization. Its determinant $\Delta=\gamma^{2} \Sigma Q_{i}$ is negative where the $Q_{i}$ are negative quadratic terms. For example, the $Q_{i}$ for the own partial derivative of capital with respect to its price is $\partial \mathrm{K} / \partial \mathrm{r}=-\gamma\left(\mathrm{Y}_{\mathrm{L}}{ }^{2} \mathrm{Y}_{\mathrm{EE}}+\mathrm{Y}_{\mathrm{E}}{ }^{2} \mathrm{Y}_{\mathrm{LL}}-2 \mathrm{Y}_{\mathrm{L}} \mathrm{Y}_{\mathrm{E}} \mathrm{Y}_{\mathrm{LE}}\right) / \Delta<0$. Concavity is ensured by positive diminishing marginal products in $Y_{\mathrm{i}}>0$ and $\mathrm{Y}_{\mathrm{ii}}<0$ and by $\mathrm{Y}_{\mathrm{ik}}>0$. In the present estimates, concavity is tested as a null hypothesis.

Factor price elasticities are derived from the partial derivatives of (2). For instance, $\left.\partial \mathrm{K} / \partial \mathrm{e}=\gamma\left[\mathrm{Y}_{\mathrm{E}} \mathrm{Y}_{\mathrm{K}} \mathrm{Y}_{\mathrm{LL}}+Y_{L}^{2} \mathrm{Y}_{\mathrm{KE}}-\mathrm{Y}_{\mathrm{L}} \mathrm{Y}_{\mathrm{E}} \mathrm{Y}_{\mathrm{KL}}-\mathrm{Y}_{\mathrm{K}} \mathrm{Y}_{\mathrm{L}} \mathrm{Y}_{\mathrm{LE}}\right)\right] / \Delta$ leading to the elasticity of capital with respect to the price of energy $\varepsilon_{\mathrm{Ke}} \equiv(\partial \mathrm{K} / \partial \mathrm{e})\left(\mathrm{Y}_{\mathrm{E}} / \mathrm{K}\right)$. Complements $\partial \mathrm{K} / \partial \mathrm{e}=\partial \mathrm{E} / \partial \mathrm{r}<$ 0 would be favored by a positive $Y_{\mathrm{KE}}>0$ as an increase in the price of energy lowering $\mathrm{E}$ input would reduce $Y_{K}$ favoring a reduction in $\mathrm{K}$ as well. A negative effect with labor would also 
favor $\mathrm{KE}$ complements as the reduced $\mathrm{K}$ and $\mathrm{E}$ inputs would raise the marginal product $\mathrm{Y}_{\mathrm{L}}$ of labor making it more attractive.

\section{The Empirical Literature on KLE Cross Price Elasticities}

Estimates of factor price elasticities including energy input typically find weak cross price substitutes as in Griffin and Gregory (1976), Chang (1994), Caloghiro, Mourelatos, and Thompson (1997), Kemfert (1998), Barnett, Reutter, and Thompson (1998), Mahmud (2000), Urga and Walters (2003), and Koetse, de Groot, and Florax (2008). Capital-energy complements are reported by Berndt and Wood (1975), Ehud and Melnik (1981), Moroney (1992), and Frondel and Schmidt (2002). This literature mostly relies on estimates of translog cost or production function share equations as reviewed by Apostolakis (1990) and Thompson (2006).

Refinements in methodology include a model of noncompetitive pricing for energy input in Capros, Karadeloglou, and Mentzas (1989) who find negative output elasticities for labor in Europe. Kummel, Henn, and Lindenberger (2002) develop a model of technological change finding overpaid labor at the expense of underpaid energy in the US, Japan, and Germany. Ayres, van der Bergh, Lindenberger, and Warr (2013) and Ayres and Voudouris (2014) uncover nonlinear relationships between output and inputs of capital, labor, and energy. Energy is shown to be a critical input by van der Werf (2008) who does not reject the assumption of nesting energy with capital and labor. Thompson (2016) introduces a production function motivated by the definition of work in physics with both labor and Btu energy providing force for work.

Recent capital-labor estimates introduce techniques that could be applied to specifications including energy input. Pintus (2006) estimates price elasticities under a general form of technology. Juselius (2008) develops an indirect estimate based on behavioral equations. Raurich, Sala, and Sorolla (2012) estimate a model with imperfect competition in the labor market.

\section{The Series, Average Products, and Factor Intensities}

Figure 1 shows the mean weighted series of the present data covering the years 1949 to 2013 . Indices of US gross domestic product $Y$ and fixed capital assets K are both 100 in 2009. The mean of the full-time equivalent labor force $\mathrm{L}$ in millions is 83.6. The mean of energy Btu input $\mathrm{E}$ is 58.2. The $\mathrm{Y}, \mathrm{K}$, and $\mathrm{L}$ series are from the Federal Reserve Economic Data FRED (2019) and the E series from the Energy Information Agency (2019). 
THOMPSON Trends in Factor Price Elasticities

Figure 1. US Output and Factor Input Data Relative to Means

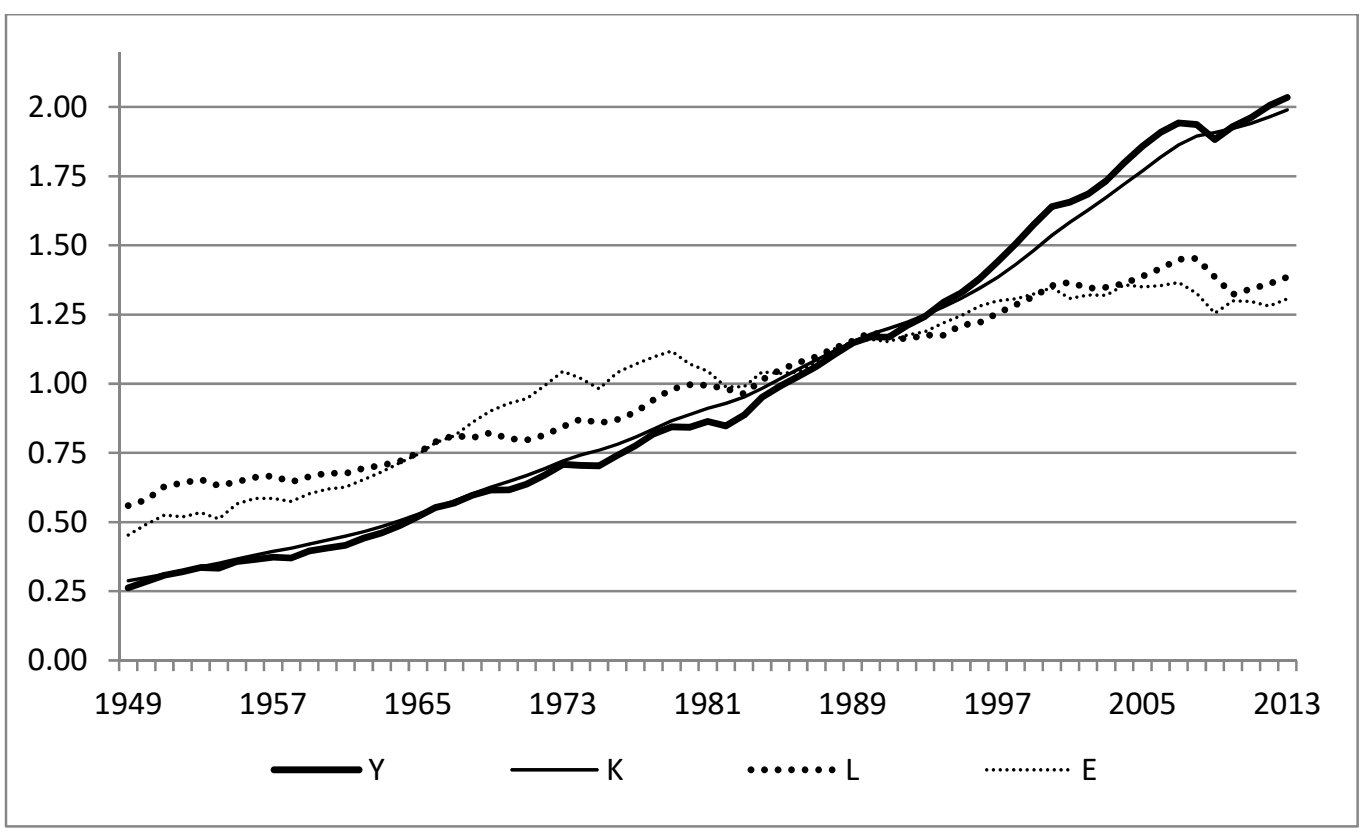

Sources: $\quad Y=$ GDP index from Federal Reserve Economic Data FRED (2019)

$\mathrm{K}=$ Fixed capital assets index from FRED (2019)

$\mathrm{L}=$ Full time equivalent labor force from FRED (2019)

E = Energy Btu input from Energy Information Agency (2019)

Output and capital increase at slightly increasing rates while labor and energy increase at slower steady rates. The labor force has periodic episodes of slow growth and decline. The increasing trend in energy decelerates at the energy crises during the 1970s and 1980s. Capital characterized by periodic jumps followed by gradually slower growth is highly dependent on any number of lags. The labor series is characterized by periodic increases followed by slow unsteady declines, suggesting sticky employment. The energy series has the highest variation. The trend in output appears to depend on fixed capital assets with variation around the trend due to labor and energy inputs.

Figure 2 plots the average products of the three inputs derived from their mean weighted values in Figure 1. The average product $\mathrm{Y} / \mathrm{K}$ of capital as a ratio of those two indices is relatively stable. The average product $\mathrm{Y} / \mathrm{L}$ of labor generally grows steadily at an average rate of $1.6 \%$ but decreases during the early $1950 \mathrm{~s}$ and following the financial crisis after 2010 . 
Figure 2. Average Products of Factors

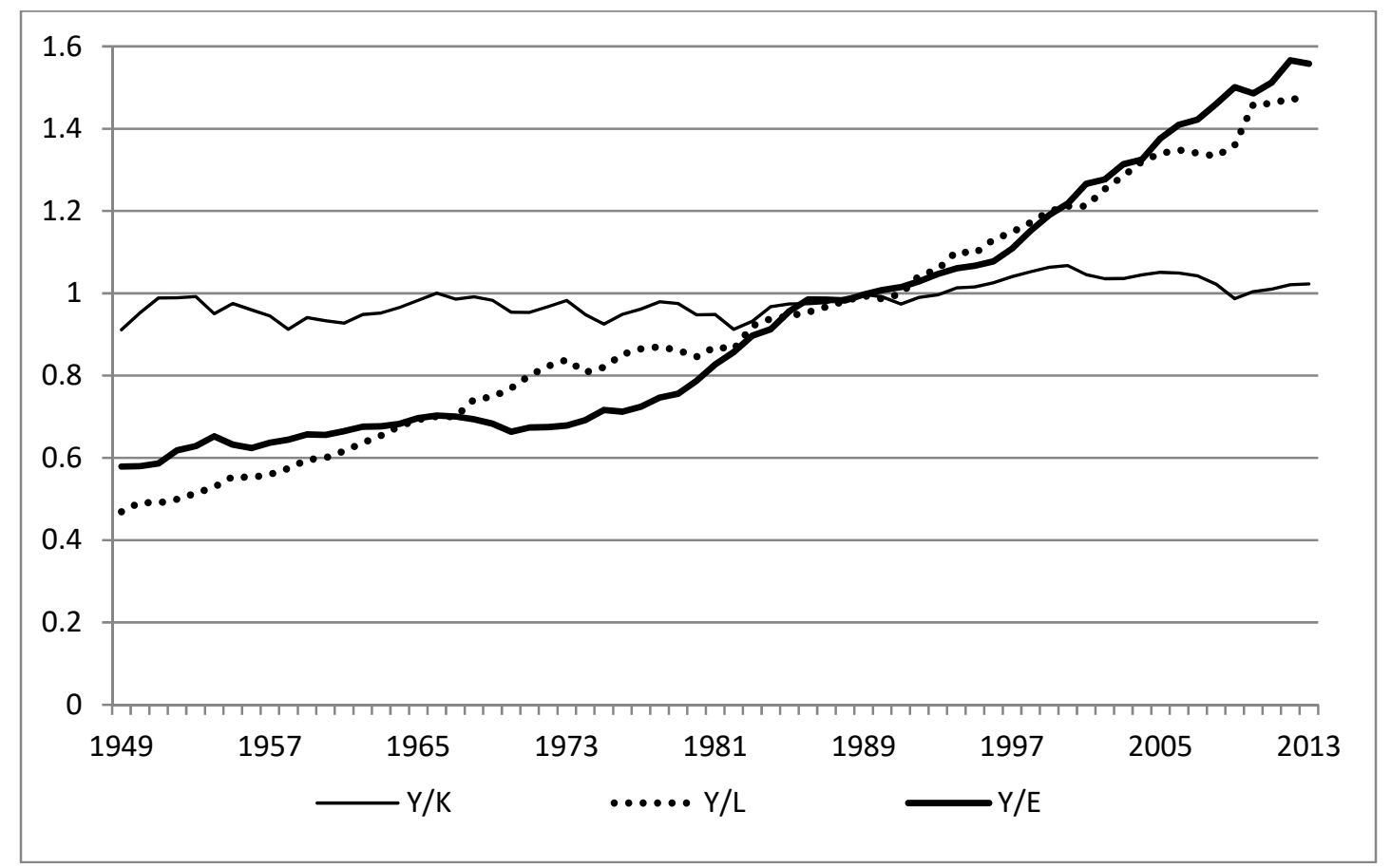

Sources: See Figure 1

A structural break for the financial crisis proves insignificant. The average product $\mathrm{Y} / \mathrm{E}$ of energy changes from a steady decline to an increasing trend at the energy crisis, evidence of improving energy efficiency of investment. The structural break at for the energy crisis in 1973 proves significant.

Figure 3 compares trends in the three factor intensities. Capital-labor intensity K/L increases at a steady pace with occasional jumps. The two energy intensities K/E and L/E increase following the energy crisis as the economy becomes less energy intensive due to the higher price of energy. Overall, capital intensity has increased while labor intensity has decreased relative to capital but reversed to an increase relative to energy. These trends suggest the capital return falls relative to the wage and price of energy, with the wage switching to a decrease relative to the price of energy at the energy crisis.

Figure 4 shows percentage changes of the series as differences of natural logs. The means (standard deviations) are 3.20 (2.33) for $\Delta \operatorname{lnY}, 3.02(0.92)$ for $\Delta \ln K, 1.40$ (2.40) for $\Delta \operatorname{lnL}$, and 1.65 (3.19) for $\Delta \operatorname{lnE}$. Capital grows at a much steadier pace than labor or especially energy. The apparent downward trend in Figure 4 proves insignificant in the estimates. 
Figure 3. Factor Intensities Based on Mean Weighted Series

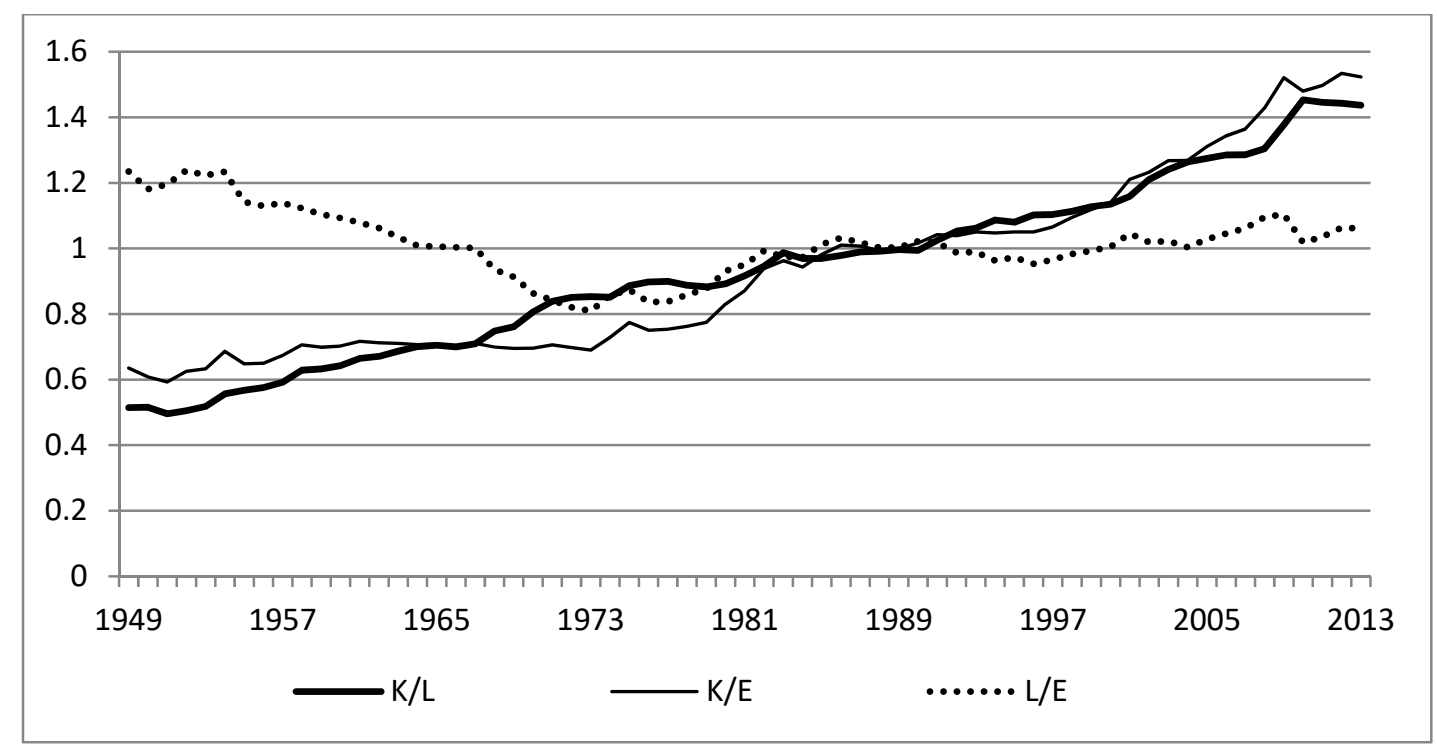

Sources: See Figure 1

Figure 4. Percentage Changes in Series

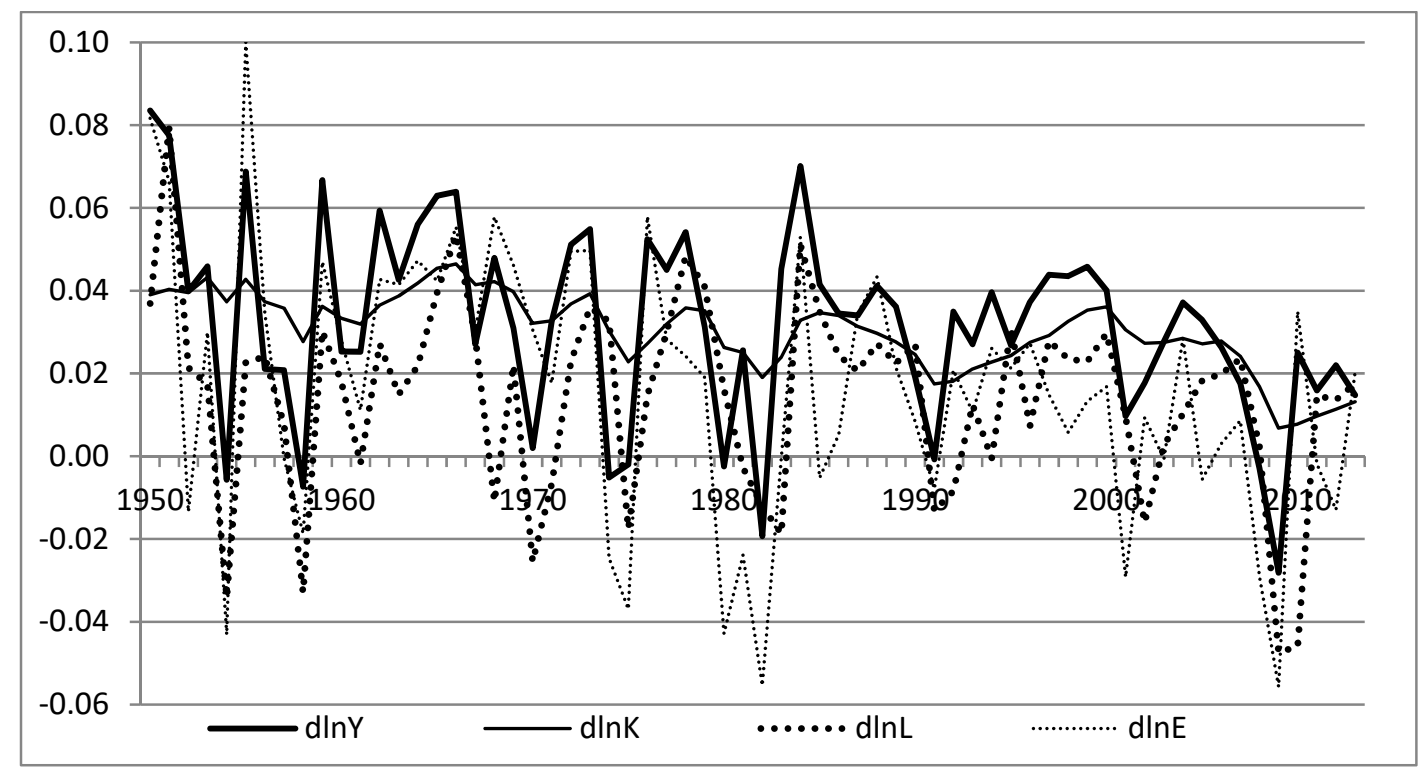

Sources: See Figure 1. 
Table 1 reports augmented Dickey-Fuller ADF pretests for natural logs of the series that prove difference stationary except for labor that has persistence over any number of lags. Labor is not double difference stationary in unreported tests. The difference equation estimates of (2) nevertheless have reliable econometric properties. There is no evidence of residual correlation in the $\rho$ coefficients, and no evidence of residual heteroskedasticity in the Arch(1) coefficients.

Table 1. Difference stationary ADF tests

\begin{tabular}{|l|l|l|l|l|l|l|}
\hline $\mathrm{d} \ln \mathrm{V}$ & const & $\mathrm{V}_{-1} \times 10^{-3}$ & $\mathrm{tx} 10^{-3}$ & $\mathrm{dln}_{-1}$ & $\rho$ & $\operatorname{Arch}(1)$ \\
\hline $\mathrm{Y}$ & $\begin{array}{l}1.33 \\
(1.53)\end{array}$ & $\begin{array}{l}-0.65 \\
(0.49)\end{array}$ & $\begin{array}{l}0.70 \\
(0.78)\end{array}$ & $\begin{array}{l}0.15 \\
(0.12)\end{array}$ & -0.06 & 0.47 \\
\hline $\mathrm{K}$ & $\begin{array}{l}-0.28 \\
(0.80)\end{array}$ & $\begin{array}{l}-0.17 \\
(0.12)\end{array}$ & $\begin{array}{l}0.15 \\
(0.18)\end{array}$ & $\begin{array}{l}0.75^{*} \\
(0.08)\end{array}$ & $0.21^{*}$ & -0.001 \\
\hline $\mathrm{L}$ & $\begin{array}{l}-5.15^{*} \\
(1.94)\end{array}$ & $\begin{array}{l}-2.81^{*} \\
(0.81)\end{array}$ & $\begin{array}{l}2.70^{*} \\
(1.01)\end{array}$ & $\begin{array}{l}0.38^{*} \\
(0.12)\end{array}$ & -0.05 & -0.19 \\
\hline $\mathrm{E}$ & $\begin{array}{l}-1.14 \\
(1.51)\end{array}$ & $\begin{array}{l}-1.31 \\
(0.86)\end{array}$ & $\begin{array}{l}0.62 \\
(0.74)\end{array}$ & $\begin{array}{l}0.10 \\
(0.13)\end{array}$ & -0.02 & $1.71^{*}$ \\
\hline
\end{tabular}

* significant at the $10 \%$ level

\section{Estimates of Log Linear Production Functions}

The difference stationary properties of the series in Table 1 lead to reliable estimates of difference equations. A 1973 structural break for the energy crisis proves significant and is included in all estimates while breaks for the financial crisis and a time trend are not significant. The null hypothesis of no residual correlation is not rejected by Durbin-Watson (1951) DW statistics. The null hypothesis of homoskedasticity is not rejected by Arch(1) statistics.

Table 2 reports log linear estimates for the capital-labor KL model and the capital-laborenergy KLE model. The KLE estimate without the break has almost exact CRS although the significant constant term implies an unexplained trend in output. The energy crisis structural break strengthens the output elasticity of capital due to increasingly energy efficient investment. The insignificant constant terms suggest the fixed capital asset series must successfully imbed technology.

Adding energy input raises explanatory power in the adjusted $\mathrm{R}^{2}$ values by half and reduces the labor coefficient by the same degree. The KLE estimates only marginally reject the null hypothesis of constant returns to scale CRS that the sum of the coefficients equals one. The output elasticity of energy is twice that of labor.

Table 3 compares marginal products and price elasticities evaluated in 2013 at the end of sample when $(\mathrm{Y}, \mathrm{K}, \mathrm{L}, \mathrm{E})=(108.1,104.3,115.8,76.0)$. Marginal products $Y_{K}$ of capital and $Y_{L}$ of labor are lower in the KLE model than in the KL model and are consistently lower than the marginal product $Y_{K E}$ of energy. 
THOMPSON Trends in Factor Price Elasticities

Table 2. Log Linear Estimates

\begin{tabular}{|l|l|l|l|}
\hline & KL & KLE & KLE \\
\hline \multirow{2}{*}{ constant } & 0.001 & $0.012^{\dagger}$ & -0.002 \\
& $(0.008)$ & $(0.005)$ & $(0.009)$ \\
\hline \multirow{2}{*}{$\ln \mathrm{l}$} & $\begin{array}{l}0.89^{\ddagger} \\
(0.26)\end{array}$ & $\begin{array}{l}0.26 \\
(0.19)\end{array}$ & $\begin{array}{l}0.60^{\dagger} \\
(0.26)\end{array}$ \\
\hline \multirow{2}{*}{$\operatorname{lnL}$} & $\begin{array}{l}0.46^{\ddagger} \\
(0.10)\end{array}$ & $\begin{array}{l}0.28^{\ddagger} \\
(0.07)\end{array}$ & $\begin{array}{l}0.21^{\dagger} \\
(0.08)\end{array}$ \\
\hline \multirow{2}{*}{$\operatorname{lnE}$} & & $\begin{array}{l}0.46^{\ddagger} \\
(0.05)\end{array}$ & $\begin{array}{l}0.49^{\ddagger} \\
(0.06)\end{array}$ \\
\hline \multirow{2}{*}{ break73 $^{*}$} & & & $0.008^{*}$ \\
& & & $(0.004)$ \\
\hline adjR ${ }^{2}$ & 0.521 & 0.779 & 0.778 \\
\hline DW & 2.14 & 1.85 & 1.80 \\
\hline Arch(1) & -0.17 & -1.24 & -0.73 \\
\hline \multirow{2}{*}{ CRS } & 1.35 & 1.02 & 1.30 \\
& $(0.28)$ & $(0.21)$ & $(0.28)$ \\
\hline
\end{tabular}

* $10 \% \quad \dagger 5 \% \quad \$ 1 \%$

Table 3. Log Linear Productivities and Price Elasticities, 2013

\begin{tabular}{|l|l|l|l|l|l|l|l|}
\hline & $\mathrm{KL}$ & & & & $\varepsilon_{\mathrm{ik}}$ & & \\
\hline $\mathrm{Y}_{\mathrm{K}}$ & 0.92 & $\mathrm{Y}_{\mathrm{L}}$ & 0.43 & & $\mathrm{~K}$ & $\mathrm{~L}$ & \\
\hline $\begin{array}{c}\mathrm{Y}_{\mathrm{K}} \\
\mathrm{K}\end{array}$ & -0.0010 & $\mathrm{Y}_{\mathrm{KL}}$ & 0.0037 & $\mathrm{r}$ & -0.34 & 0.34 & \\
\hline $\mathrm{Y}_{\mathrm{LL}}$ & -0.0020 & & & $\mathrm{w}$ & 0.66 & -0.66 & \\
\hline & & & & & & & \\
\hline & $\mathrm{KLE}$ & & & & & & \\
\hline $\mathrm{Y}_{\mathrm{K}}$ & 0.62 & $\mathrm{Y}_{\mathrm{L}}$ & 0.19 & & $\varepsilon_{\mathrm{ik}}$ & & \\
\hline $\mathrm{Y}_{\mathrm{E}}$ & 0.69 & & & & $\mathrm{~K}$ & $\mathrm{~L}$ & $\mathrm{E}$ \\
\hline $\mathrm{Y}_{\mathrm{K}}$ & & $\mathrm{Y}_{\mathrm{KL}}$ & 0.0011 & $\mathrm{r}$ & -0.54 & 0.16 & 0.38 \\
$\mathrm{~K}$ & -0.0024 & $\mathrm{Y}_{\mathrm{KE}}$ & 0.0040 & $\mathrm{w}$ & 0.46 & -0.84 & 0.38 \\
\hline $\mathrm{Y}_{\mathrm{LL}}$ & -0.0013 & $\mathrm{Y}_{\mathrm{LE}}$ & 0.0012 & $\mathrm{e}$ & 0.46 & 0.16 & -0.62 \\
\hline $\mathrm{Y}_{\mathrm{EE}}$ & -0.0047 & & & & &
\end{tabular}

Adding energy input increases the second order own capital effect $Y_{\mathrm{KK}}$ and diminishes the impact of labor in the second order $Y_{L L}$ and $Y_{E E}$ own effects in Table 3. The effect $Y_{K E}$ of energy on the marginal product of capital is larger than the effect $Y_{\mathrm{KL}}$ of labor. Adding energy increases the own capital elasticity $\varepsilon_{\mathrm{Kr}}$ and the own labor elasticity $\varepsilon_{\mathrm{Lw}}$ but reduces their cross price elasticities $\varepsilon_{\mathrm{Lr}}$ and $\varepsilon_{\mathrm{Kw}}$. Energy is a moderate substitute relative to the prices of capital and labor in $\varepsilon_{\mathrm{Er}}$ and $\varepsilon_{\mathrm{Ew}}$. Relative to the price of energy, labor is a weak substitute in $\varepsilon_{\mathrm{Le}}$ and 
capital a moderate substitute in $\varepsilon_{\mathrm{Ke}}$. The strongest elasticity for own labor $\varepsilon_{\mathrm{Lw}}$ is amplified by second order effects.

\section{Production Function Estimates with Second Order Effects}

Table 4 presents estimates of the production function (3) with viable second order effects. The KE-LE model with those two second order effects violates concavity. The KE-KL-LE model has no significant coefficients. Any estimate with a second order own effect violates concavity.

Table 4. Estimates with Second Order Effects

\begin{tabular}{|c|c|c|c|c|c|c|}
\hline & KL & $\mathrm{KLE}_{\mathrm{KL}}$ & $\mathrm{KLE}_{\mathrm{KE}}$ & $\mathrm{KLE}_{\mathrm{LE}}$ & $\begin{array}{l}\text { KLE }_{\text {KL- }} \\
\text { KE }\end{array}$ & $\begin{array}{l}\text { KLE }_{\mathrm{KL}-} \\
\mathrm{LE}\end{array}$ \\
\hline constant & $\begin{array}{l}0.003 \\
(0.01)\end{array}$ & $\begin{array}{l}-0.008 \\
(0.010)\end{array}$ & $\begin{array}{l}-0.006 \\
(0.010)\end{array}$ & $\begin{array}{l}-0.008 \\
(0.010)\end{array}$ & $\begin{array}{l}0.008 \\
(0.01)\end{array}$ & $\begin{array}{l}-0.009 \\
(0.010)\end{array}$ \\
\hline $\ln K$ & $\begin{array}{l}1.50^{*} \\
(0.41)\end{array}$ & $\begin{array}{l}1.25^{\dagger} \\
(0.49)\end{array}$ & $\begin{array}{l}0.93^{\dagger} \\
(0.43)\end{array}$ & $\begin{array}{l}0.72^{\ddagger} \\
(0.27)\end{array}$ & $\begin{array}{l}1.26^{\dagger} \\
(0.51)\end{array}$ & $\begin{array}{l}1.12^{*} \\
(0.66)\end{array}$ \\
\hline $\operatorname{lnL}$ & $\begin{array}{l}1.14^{\ddagger} \\
(0.37)\end{array}$ & $\begin{array}{l}0.65^{\dagger} \\
(0.30)\end{array}$ & $\begin{array}{l}0.18^{\dagger} \\
(0.09)\end{array}$ & $\begin{array}{l}0.71^{\dagger} \\
(0.36)\end{array}$ & $\begin{array}{l}0.64 \\
(0.40) \\
\end{array}$ & $\begin{array}{l}0.71^{*} \\
(0.36)\end{array}$ \\
\hline $\ln E$ & & $\begin{array}{l}0.47^{\ddagger} \\
(0.06)\end{array}$ & $\begin{array}{l}0.73^{\ddagger} \\
(0.26)\end{array}$ & $\begin{array}{l}1.05^{\dagger} \\
(0.40)\end{array}$ & $\begin{array}{l}0.48 \\
(0.33)\end{array}$ & $\begin{array}{l}0.68 \\
(0.70) \\
\end{array}$ \\
\hline KL & $\begin{array}{l}-0.18^{*} \\
(0.09)\end{array}$ & $\begin{array}{l}-0.12 \\
(0.08)\end{array}$ & & & $\begin{array}{l}-0.12 \\
(0.10)\end{array}$ & $\begin{array}{l}-0.09 \\
(0.14)\end{array}$ \\
\hline $\mathrm{KE}$ & & & $\begin{array}{l}0.07 \\
(0.07)\end{array}$ & & $\begin{array}{l}-0.003 \\
(0.09)\end{array}$ & \\
\hline LE & & & & $\begin{array}{l}-0.13 \\
(0.09)\end{array}$ & & $\begin{array}{l}-0.05 \\
(0.16)\end{array}$ \\
\hline break $_{73}$ & & $\begin{array}{l}0.012^{\dagger} \\
(0.005)\end{array}$ & $\begin{array}{l}0.011^{\dagger} \\
(0.005)\end{array}$ & $\begin{array}{l}0.011^{\dagger} \\
(0.005)\end{array}$ & $\begin{array}{l}0.012^{\dagger} \\
(0.006)\end{array}$ & $\begin{array}{l}0.013^{\dagger} \\
(0.005)\end{array}$ \\
\hline $\operatorname{adj}^{2}$ & 0.548 & 0.783 & 0.777 & 0.781 & 0.779 & 0.779 \\
\hline DW & 2.12 & 1.82 & 1.80 & 1.80 & 1.85 & 1.81 \\
\hline $\operatorname{Arch}(1)$ & 0.49 & -0.64 & -0.58 & -0.49 & -0.52 & -0.57 \\
\hline$\varphi_{\mathrm{K}}$ & $\begin{array}{l}0.65 \\
(0.60)\end{array}$ & $\begin{array}{l}0.66 \\
(0.63)\end{array}$ & $\begin{array}{l}0.64 \\
(0.52)\end{array}$ & $\begin{array}{l}0.72 \\
(0.27)\end{array}$ & $\begin{array}{l}0.66 \\
(0.80)\end{array}$ & $\begin{array}{l}0.69 \\
(0.94)\end{array}$ \\
\hline$\varphi_{\mathrm{L}}$ & $\begin{array}{l}0.31 \\
(0.57) \\
\end{array}$ & $\begin{array}{l}0.07 \\
(0.48) \\
\end{array}$ & $\begin{array}{l}0.18^{\dagger} \\
(0.09)\end{array}$ & $\begin{array}{l}0.13^{\ddagger} \\
(0.36)\end{array}$ & $\begin{array}{l}0.07 \\
(0.63) \\
\end{array}$ & $\begin{array}{l}0.08 \\
(1.07) \\
\end{array}$ \\
\hline constant & $\begin{array}{l}0.003 \\
(0.01)\end{array}$ & $\begin{array}{l}-0.008 \\
(0.010)\end{array}$ & $\begin{array}{l}-0.006 \\
(0.010)\end{array}$ & $\begin{array}{l}-0.008 \\
(0.010)\end{array}$ & $\begin{array}{l}0.008 \\
(0.01)\end{array}$ & $\begin{array}{l}-0.009 \\
(0.010)\end{array}$ \\
\hline$\varphi_{\mathrm{E}}$ & & $\begin{array}{l}0.47^{\star} \\
(0.06)\end{array}$ & $\begin{array}{l}0.42 \\
(0.41)\end{array}$ & $\begin{array}{l}0.42 \\
(0.41)\end{array}$ & $\begin{array}{l}0.47 \\
(0.53)\end{array}$ & $\begin{array}{l}(0.45) \\
(0.94)\end{array}$ \\
\hline CRS & $\begin{array}{l}0.95 \\
(0.83)\end{array}$ & $\begin{array}{l}1.20 \\
(0.79)\end{array}$ & $\begin{array}{l}1.25 \\
(0.67)\end{array}$ & $\begin{array}{l}1.27 \\
(0.60)\end{array}$ & $\begin{array}{l}1.20 \\
(1.15)\end{array}$ & $\begin{array}{l}1.22 \\
(1.76)\end{array}$ \\
\hline
\end{tabular}

${ }^{*} 10 \% \quad \dagger 5 \% \quad \$ 1 \%$ 
Adding energy input to the capital-labor model increases explanatory power by half and lowers the first order effects of labor to the same degree. First order coefficients of capital are consistent and robust. Estimates do not reject CRS as indicated by the sum (SE) of the derived $\varphi_{i}$ terms. The second order effects improve the fit of the production surface but increase imprecision.

Table 5 summarizes derived marginal products and price elasticities evaluated at the end of sample as in Table 3. Adding energy noticeably lowers the marginal product $Y_{L}$ of labor. The positive $Y_{\mathrm{KE}}$ favors complements consistent with estimates in the literature. The negative $\mathrm{Y}_{\mathrm{KL}}$ favors strong capital-labor substitutes.

An increase in the wage would reduce the labor share of income given the elastic own wage effect $\varepsilon L w$ with elastic substitution toward capital in $\varepsilon_{\mathrm{Kw}}$. The negative KL terms contribute to elastic substitution toward capital.

Decreased labor input due to an increase in the wage would raise the marginal product of capital due to the negative second order effect. Investment is labor saving and energy efficient in the negative $\varepsilon_{\mathrm{Ew}}$ and the KL effects.

An increase in the price of capital leads to a moderate own effect in the $\varepsilon_{\mathrm{Kr}}$ elasticities with consistently more substitution toward energy in $\varepsilon_{\mathrm{Er}}$ than toward labor in $\varepsilon_{\mathrm{Lr}}$. These two cross price elasticities are moderate to weak regardless of second order effects. Adding energy input diminishes the apparent substitution toward labor due to an increase in the price of capital by at least half comparing $\varepsilon_{\mathrm{Lr}}$ in the KL and KLE models.

An increase in the price of energy leads to a moderate own effect in $\varepsilon_{\mathrm{Ee}}$ with substitution toward capital in the $\varepsilon_{\mathrm{Ke}}$ elasticities across all specifications. Labor is a very weak substitute or weak complement relative to the price of energy in $\varepsilon_{\mathrm{Le}}$. The two negative LE effects favor labor as a substitute but capital effects favor weak labor-energy complements in $\varepsilon_{\text {Le }}$.

\section{Trends in Marginal Products and Price Elasticities}

Trends in marginal products and price elasticities for the second order KL model and the KLKE model are shown in Figures 5-9. The trends in all KLE models in Table 4 are very similar to the KL-KE model. The marginal product of capital in Figure 5 is relatively high and stable across all models. Adding energy input, the marginal product of labor is reduced and has a negative trend. The marginal product of energy accelerates its upward trend following the energy crisis and surpasses labor.

Figure 6 compares trends in the own capital and own labor elasticities. The moderate own capital elasticity has a slight upward trend in the KL model but a downward trend in the KLE model. The own labor elasticities are much stronger, decreasing at an increasing rate and becoming elastic.

Figure 7 compares capital-labor KL cross price elasticities. The elasticity of capital input $\mathrm{K}$ relative to the wage $\mathrm{w}$ trends to become stronger and elastic while the more moderate 
elasticity of labor $\mathrm{L}$ relative to the price $\mathrm{r}$ of capital weakens. Adding energy input accelerates the divergence of cross price elasticities related to the wage.

Table 5. Productivities and Price Elasticities, 2013

\begin{tabular}{|c|c|c|c|c|c|c|c|c|}
\hline \multicolumn{9}{|l|}{ KL } \\
\hline $\mathrm{Y}_{\mathrm{K}}$ & 0.66 & $\mathrm{Y}_{\mathrm{L}}$ & 0.20 & $\varepsilon_{\mathrm{ik}}$ & & $\mathrm{K}$ & $\mathrm{L}$ & \\
\hline $\mathrm{Y}_{\mathrm{KK}}$ & -0.0044 & $\mathrm{Y}_{\mathrm{KL}}$ & 0.0002 & & $\mathrm{r}$ & -0.52 & 0.52 & \\
\hline$Y_{L L}$ & -0.0016 & & & & $\mathrm{~W}$ & 1.08 & -1.08 & \\
\hline \multicolumn{9}{|l|}{ KLE } \\
\hline & KL & & & & & & & \\
\hline $\mathrm{Y}_{\mathrm{K}}$ & 0.69 & $\mathrm{Y}_{\mathrm{L}}$ & 0.07 & $\varepsilon_{\mathrm{ik}}$ & & $\mathrm{K}$ & $\mathrm{L}$ & $E$ \\
\hline $\mathrm{Y}_{\mathrm{E}}$ & 0.67 & & & & $\mathrm{r}$ & -0.67 & 0.20 & 0.48 \\
\hline $\mathrm{Y}_{\mathrm{KK}}$ & -0.0022 & $\mathrm{Y}_{\mathrm{KL}}$ & -0.0007 & & $\mathrm{~W}$ & 1.83 & -1.40 & -0.43 \\
\hline$Y_{L L}$ & -0.0005 & $\mathrm{Y}_{\mathrm{KE}}$ & 0.0042 & & $\mathrm{e}$ & 0.67 & -0.06 & -0.61 \\
\hline \multirow[t]{2}{*}{$\mathrm{Y}_{\mathrm{EE}}$} & -0.0047 & $\mathrm{Y}_{\mathrm{LE}}$ & 0.0004 & & & & & \\
\hline & $\mathrm{KE}$ & & & & & & & \\
\hline$Y_{K}$ & 0.67 & $\mathrm{Y}_{\mathrm{L}}$ & 0.17 & $\varepsilon_{\mathrm{ik}}$ & & $\mathrm{K}$ & $\mathrm{L}$ & $E$ \\
\hline$Y_{E}$ & 0.60 & & & & $\mathrm{r}$ & -0.54 & 0.15 & 0.40 \\
\hline $\mathrm{Y}_{\mathrm{KK}}$ & -0.0023 & $\mathrm{Y}_{\mathrm{KL}}$ & 0.0010 & & $\mathrm{~W}$ & 0.52 & -0.84 & 0.32 \\
\hline$Y_{L L}$ & -0.0012 & $\mathrm{Y}_{\mathrm{KE}}$ & 0.0028 & & $\mathrm{e}$ & 0.61 & 0.14 & -0.74 \\
\hline \multirow[t]{2}{*}{$\mathrm{Y}_{\mathrm{EE}}$} & -0.0046 & $\mathrm{Y}_{\mathrm{LE}}$ & 0.0009 & & & & & \\
\hline & $\mathrm{KL}$ & & & & & & & \\
\hline$Y_{K}$ & 0.69 & $\mathrm{Y}_{\mathrm{L}}$ & 0.06 & $\varepsilon_{\mathrm{ik}}$ & & $\mathrm{K}$ & $\mathrm{L}$ & $E$ \\
\hline $\mathrm{Y}_{\mathrm{E}}$ & 0.67 & & & & $\mathrm{r}$ & -0.68 & 0.20 & 0.48 \\
\hline $\mathrm{Y}_{\mathrm{KK}}$ & -0.0022 & $\mathrm{Y}_{\mathrm{KL}}$ & -0.0007 & & $\mathrm{~W}$ & 1.90 & -1.43 & -0.47 \\
\hline$Y_{L L}$ & -0.0005 & $\mathrm{Y}_{\mathrm{KE}}$ & 0.0043 & & $\mathrm{e}$ & 0.68 & -0.07 & -0.61 \\
\hline \multirow[t]{2}{*}{$Y_{\mathrm{EE}}$} & -0.0047 & $\mathrm{Y}_{\mathrm{LE}}$ & 0.0004 & & & & & \\
\hline & KL-KE & & & & & & & \\
\hline $\mathrm{Y}_{\mathrm{K}}$ & 0.69 & $\mathrm{Y}_{\mathrm{L}}$ & 0.07 & $\varepsilon_{\mathrm{ik}}$ & & $\mathrm{K}$ & $\mathrm{L}$ & $E$ \\
\hline$Y_{E}$ & 0.67 & & & & $\mathrm{r}$ & -0.67 & 0.20 & 0.48 \\
\hline $\mathrm{Y}_{\mathrm{KK}}$ & -0.0022 & $\mathrm{Y}_{\mathrm{KL}}$ & -0.0007 & & $\mathrm{~W}$ & 1.83 & -1.40 & -0.43 \\
\hline$Y_{L L}$ & -0.0005 & $\mathrm{Y}_{\mathrm{KE}}$ & 0.0042 & & $\mathrm{e}$ & 0.67 & -0.06 & -0.61 \\
\hline \multirow[t]{2}{*}{$Y_{\mathrm{EE}}$} & -0.0047 & $\mathrm{Y}_{\mathrm{LE}}$ & 0.0004 & & & & & \\
\hline & KL-LE & & & & & & & \\
\hline $\mathrm{Y}_{\mathrm{K}}$ & 0.72 & $\mathrm{Y}_{\mathrm{L}}$ & 0.07 & $\varepsilon_{\mathrm{ik}}$ & & $\mathrm{K}$ & $\mathrm{L}$ & $E$ \\
\hline $\mathrm{Y}_{\mathrm{E}}$ & 0.64 & & & & $\mathrm{r}$ & -0.46 & 0.09 & 0.36 \\
\hline $\mathrm{Y}_{\mathrm{KK}}$ & -0.0021 & $\mathrm{Y}_{\mathrm{KL}}$ & -0.0003 & & $\mathrm{~W}$ & 0.82 & -1.22 & 0.39 \\
\hline$Y_{L L}$ & -0.0006 & $\mathrm{Y}_{\mathrm{KE}}$ & 0.0042 & & $\mathrm{e}$ & 0.56 & 0.07 & -0.63 \\
\hline $\mathrm{Y}_{\mathrm{EE}}$ & -0.0046 & $\mathrm{Y}_{\mathrm{LE}}$ & -0.0002 & & & & & \\
\hline
\end{tabular}

Figure 8 shows trends in the energy related elasticities. Relative to the price of energy, capital is a moderate substitute with a strengthening trend while labor trends to become a weaker substitute. 
THOMPSON Trends in Factor Price Elasticities

Figure 5. Marginal products in KL and KL-KE estimates

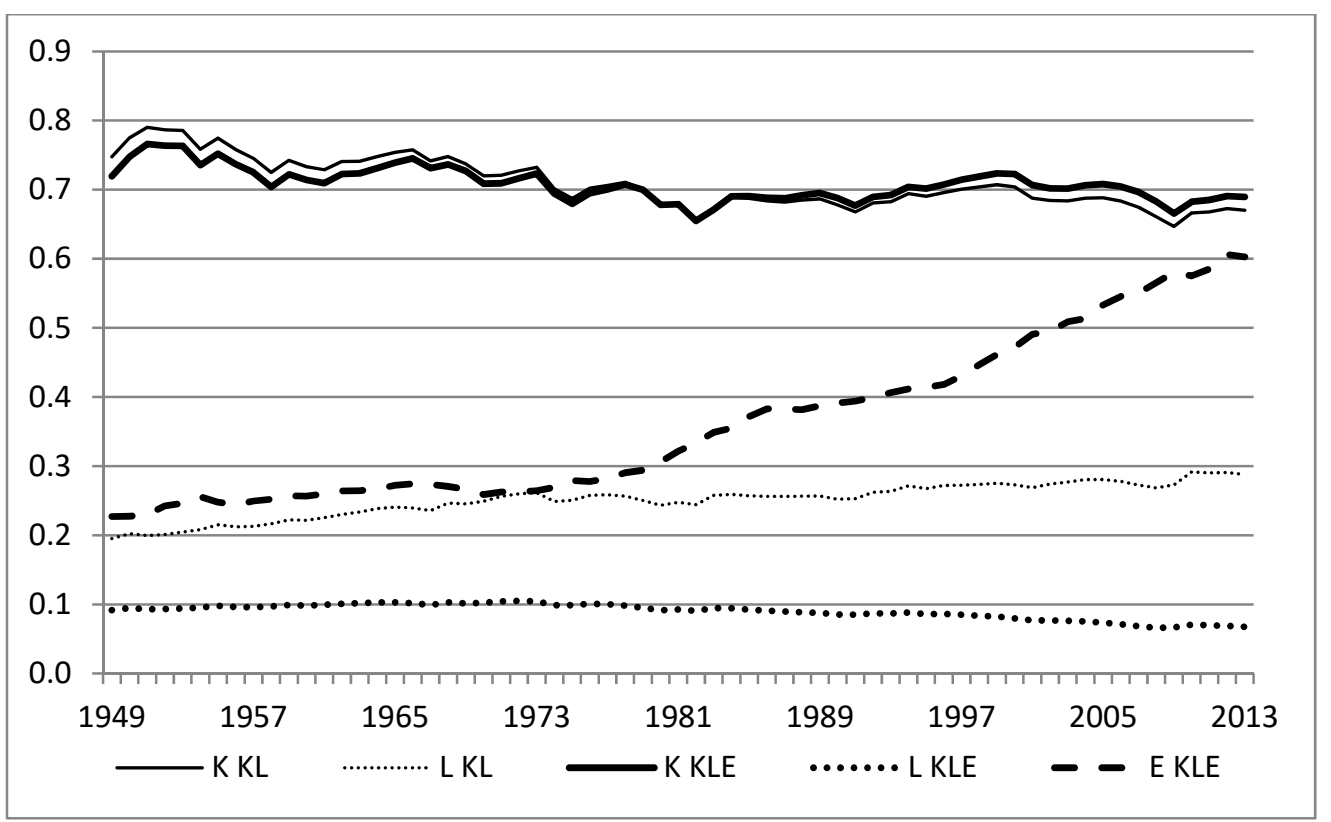

Sources: Estimates in Table 4 and derivations

Figure 6. Capital and Labor Own Elasticities in the KL and KLE Estimates

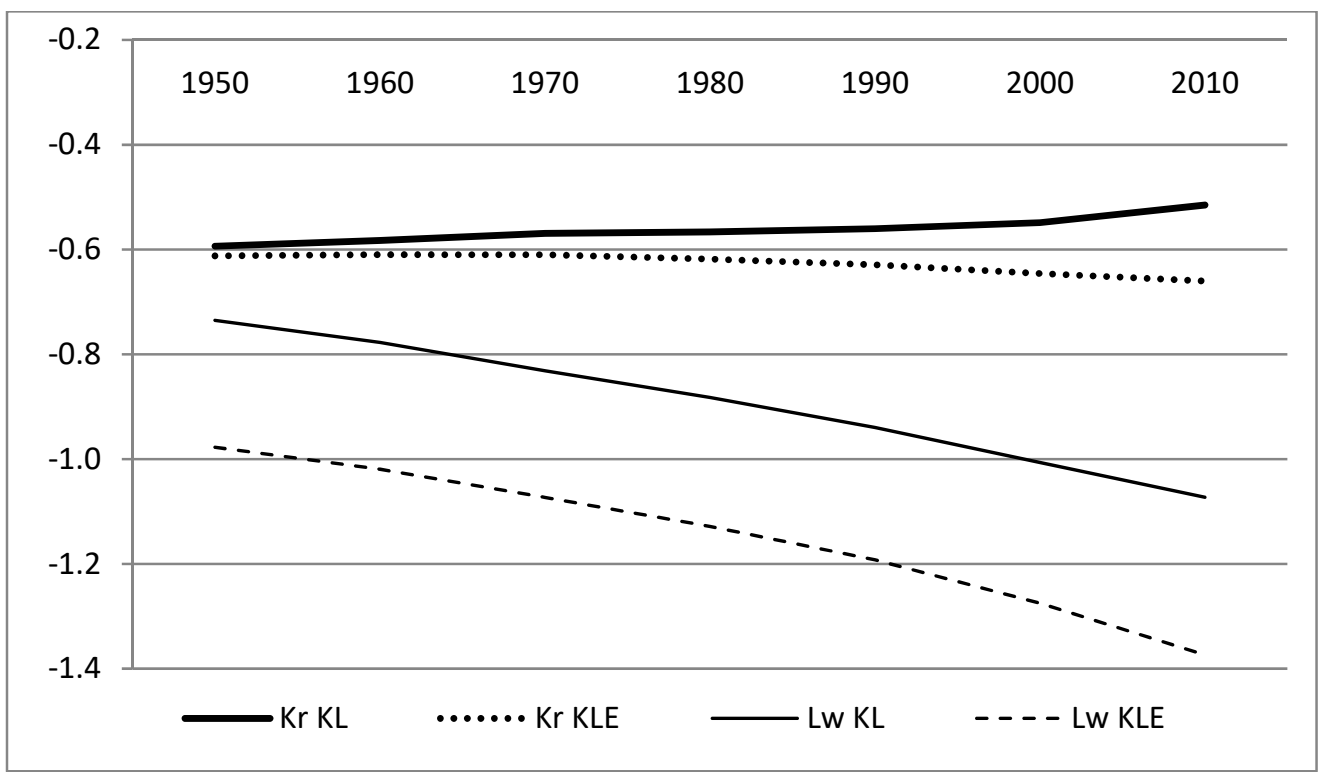

Sources: Estimates in Table 4 and derivations 
Review of Economic Analysis 11 (2019) 399-417

Figure 7. Capital and Labor Cross Price Elasticities in the KL and KLE Estimates

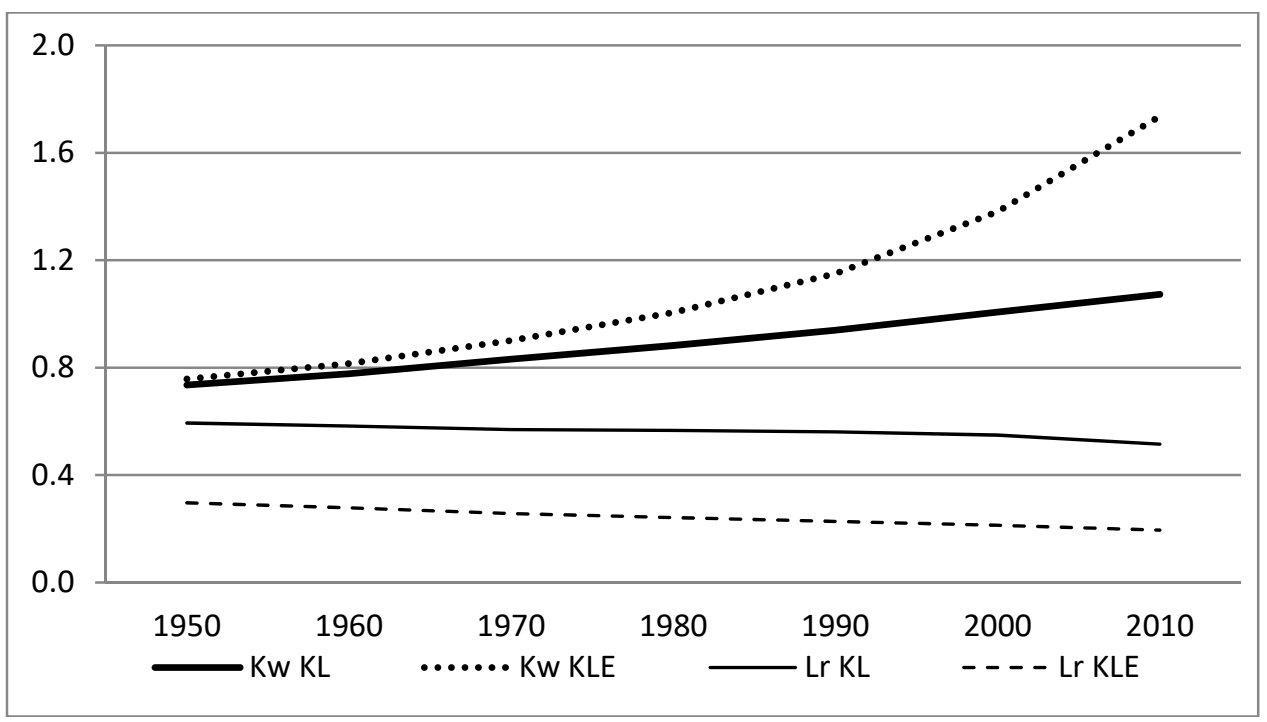

Sources: Estimates in Table 4 and derivations

Figure 8. Energy Elasticities in the KL-KE Model

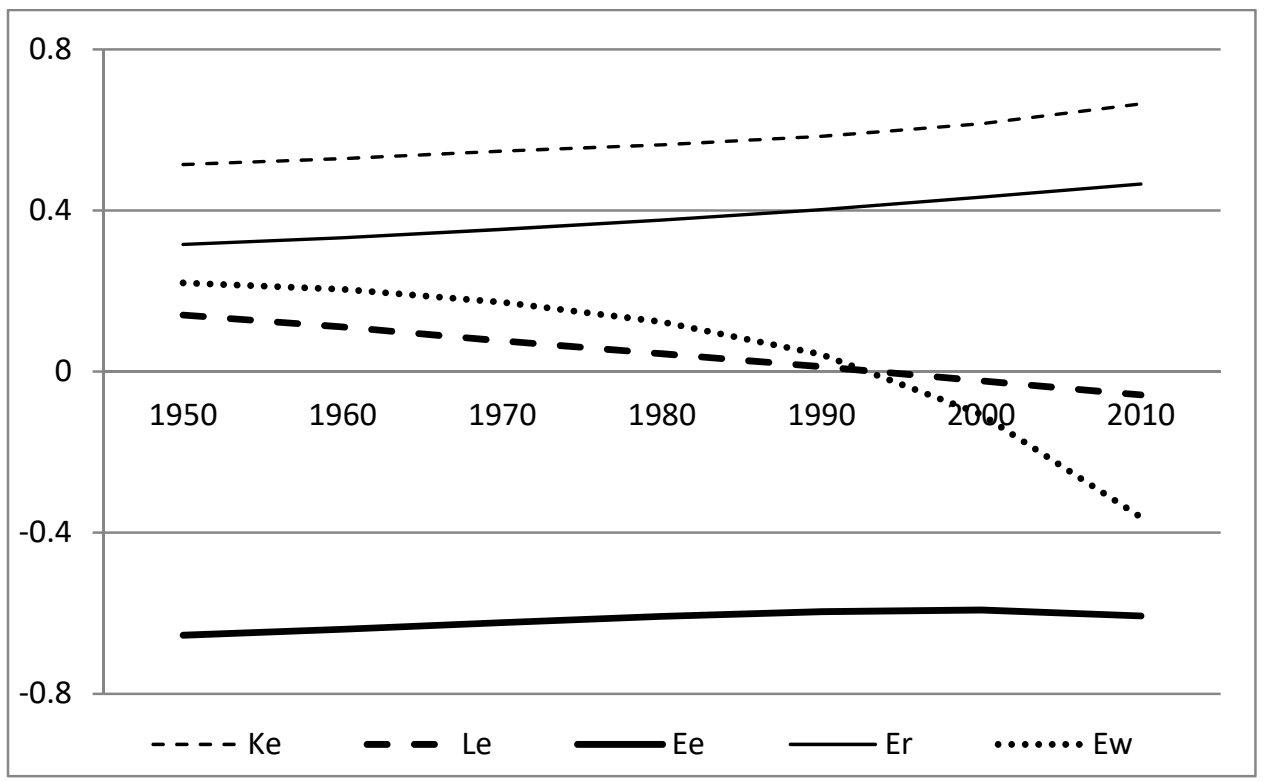

Sources: Estimates in Table 4 and derivations 
Energy trends to a stronger substitute relative to the price of capital but a weaker substitute relative to the wage. Energy and labor trend to become weak complements implying increased energy resource scarcity over the coming decades will reduce cost minimizing labor input.

Figure 9 shows the implied trends in marginal rates of substitution MRS in the KL-KE model that are similar in all KLE models. The MRS-LK of labor relative to capital is derived as the ratio of marginal products $\mathrm{Y}_{\mathrm{L}} / \mathrm{Y}_{\mathrm{K}}$ that trends upward slightly before the energy crisis and downward slightly after. The consistently rising $\mathrm{K} / \mathrm{L}$ intensity in Figure 3 suggests the wage $\mathrm{w}$ must trend above the marginal product $\mathrm{Y}_{\mathrm{L}}$ of labor after the energy crisis.

Figure 9. Marginal Rates of Substitution MRS

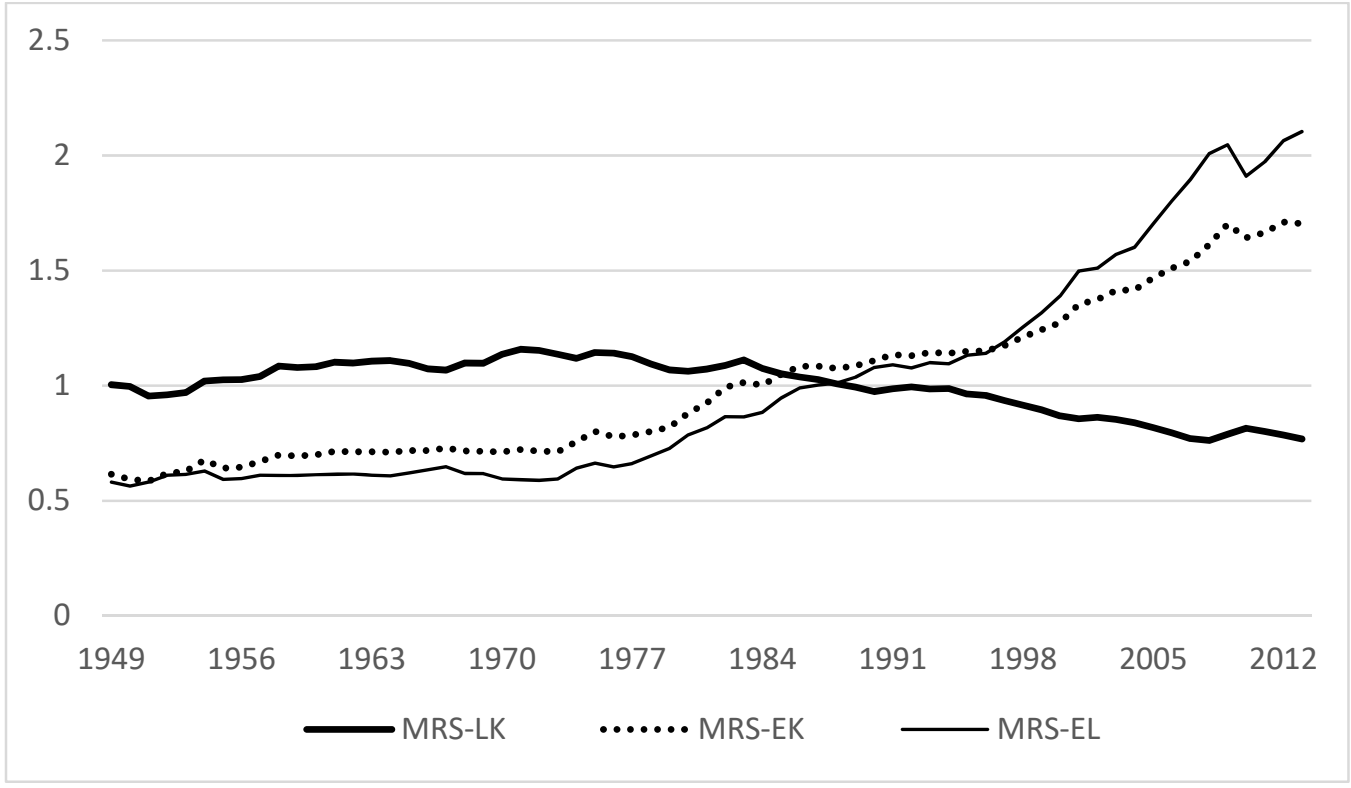

Sources: Estimates in Table 4 and derivations

The marginal rate of substitution MRS of energy relative to capital MRS-EK trends slowly upward until the energy crisis when it accelerates with the rising relative price of energy. The consistently rising K/E intensity in Figure 3 reflects competitive cost minimization for these two inputs.

The marginal rate of substitution MRS-EL of energy relative to labor is stable until the energy crisis before it begins a steady upward trend. The $\mathrm{L} / \mathrm{E}$ intensity in Figure 3 is consistent with competitive cost minimization after the energy crisis. 
Review of Economic Analysis 11 (2019) 399-417

The trends in marginal rates of substitution in Figure 9 together with the factor intensities in Figure 3 suggest the labor market is not competitive. Including energy input exposes this lack of competition.

\section{Conclusion}

The present results contribute to the evidence that energy is a critical input. Adding energy input affects the trends in factor price elasticities involving capital and labor. Energy input has a robust output elasticity rivaling that of capital and far outranking labor. The present second order effects of energy in the estimated production functions improve fit and accentuate the trends of factor price elasticities.

Capital is revealed to have a moderate but strengthening wage elasticity especially adding energy input to the estimates. Capital has a moderate energy price elasticity with a moderately strengthening trend. Energy is a weak but strengthening substitute relative to the price of capital, and a moderate but strengthening substitute relative to the wage. Energy also has a strong own price elasticity with a weakening trend suggesting increasing energy resource scarcity will raise the energy share of income. Labor is characterized by a downward trend in marginal product and strong factor price elasticities. The own labor elasticity trends to become elastic implying an increased wage would lower the labor share of income.

While a model is required to apply the present trends in factor price elasticities, a few examples can be mentioned. The upward trend in the marginal product of energy with its steady income share suggests constraints bind the energy market. One such constraint is the monopsony power of franchised electric utilities. Wars and international politics have aimed to weaken monopoly power over energy resource supply. Energy and labor trending to become complements implies rising energy prices would reduce labor demand.

Adjustments to an increase in the price of capital due to another financial crisis would depend on the moderate but upward trending own capital elasticity. There would be moderate but weakening substitution toward labor coupled with moderate but strengthening substitution toward energy. Demand for both labor and energy would increase with the higher price of capital with increasing reliance on energy.

An increase in the legislated minimum wage or union wage will generate increasingly elastic substitution away from labor toward capital. The trend of energy to become a complement with labor implies energy demand would decrease with a strong increase in the demand for capital. A higher wage would result in a reduction in the labor share of income. These present trends in wage elasticities are consistent with the mounting challenges seeming to face labor.

Economic growth that would raise the wage might have the opposite effect in a model including the trend toward labor-energy complements and an upward trending price of energy. Tariffs on labor intensive imports that would raise the wage might have the opposite effect 
including the trends toward elastic own labor and labor-energy complements. Models of industrial organization generally assume weak factor price substitutes in a capital-labor framework. Models in macroeconomics and labor economics assume weak capital-labor price elasticities. The present trends in factor price elasticities suggest a wide range of economic models should consider energy input and trends in factor price elasticities.

\section{References}

Allen, R.G.D. (1938) Mathematical Analysis for Economists, St. Martin's Press, New York.

Apostolakis, Bobby E. (1990) Energy-capital substitutability/complementarity: The dichotomy, Energy Economics 1, 48-58.

Ayres, Robert and Vlasios Voudouris (2014) The economic growth enigma: Capital, labour, and useful energy? Energy Policy 64, 16-28.

Ayres, Robert, Jeroen van den Bergh, Dietmar Lindenberger, and Bengamin Warr (2013) The underestimated contribution of energy to economic growth, Structural Change and Economic Dynamics 27, 79-88.

Barnett, Andy, Keith Reutter, and Henry Thompson (1998) Electricity substitution: Some local industrial evidence, Energy Economics 20, 411-19.

Berndt, Ernst, and Laurits Christensen (1973) The internal structure of functional relationships: Seperability, substitution, and aggregation, The Review of Economic Studies 55, 403-10.

Berndt, Ernst and D.O. Wood (1975) Technology, prices and the derived demand for labor, The Review of Economics and Statistics 57, 376-84.

Caloghiro, Yannis, Alexi Mourelatos, and Henry Thompson (1997) Industrial energy substitution during the 1980s in the Greek economy, Energy Economics 19, 476-91.

Capros, Pamtelis, Pavlos Karadeloglou, and G.N. Mestzas (1989) Energy policy extensions of KLE-based macroeconomic models, Journal of Policy Modeling 11, 507-30.

Chang, Kuo-Ping (1994) Capital-energy substitution and the multi-level CES production function, Energy Economics 16, 22-6.

Dickey, David and Wayne Fuller (1979) Distribution of the estimates for autoregressive time series with a unit root, Journal of the American Statistical Association 74, 427-31.

Denny, Michael, Melvyn Fuss, and Leonard Waverman (1981) Substitution possibilities for energy: Evidence from US and Canadian manufacturing industries, in E.R. Berndt and B.C. Field, eds., Modeling and Measuring Natural Resource Substitution, MIT Press, Cambridge.

Durbin, James and Goeffrey Watson (1951) Testing for serial correlation in least squares regression, Biometria 38, 15-178.

Ehud, Ronn and Arie Melnik (1981) The substitution of capital, labor and energy in the Israeli economy, Resources and Energy 3, 247-58. 
Energy Information Agency (2019) US Department of Energy, Primary Energy Consumption Total (www.eia.gov/totalenergy/data/monthly/pdf/sec2_3.pdf).

Ferguson, C.E. and Ralph Pfouts (1962) Aggregate production functions and relative factor shares, International Economic Review 3, 328-37.

Field, Barry and Charles Grebenstein (1980) Capital energy substitution in US manufacturing, Review of Economics and Statistics 62, 207-12.

Federal Reserve Economic Data FRED (2019) Real Gross Domestic Product (GDPC1), Current-Cost Net Stock of Fixed Assets and Consumer Durable Goods release/tables?rid=356\&eid=145899), Civilian Labor Force (LNU01000000).

Frondel, Manuel and Christopher Schmidt (2002) The capital-energy controversy: An artifact of cost shares? The Energy Journal 23, 53-79.

Griffin, James and Paul Gregory (1976) An intercountry translog model of energy substitution responses, American Economic Review 66, 845-57.

Juselius, Mikael (2008) Long-run relationships between labor and capital: Indirect evidence on the elasticity of substitution, Journal of Macroeconomics 30, 739-56.

Kemfert, Claudia (1998) Estimated substitution elasticities of a nested CES production function approach for Germany, Energy Economics 20, 249-64.

Koetse, Mark, Henri de Groot, and Raymond Florax (2008) Capital-energy substitution and shifts in factor demand: A meta-analysis, Energy Economics 30, 2236-51.

Kummel, Reiner, Julian Henn, and Dietmar Lindenberger (2002) Capital, labor, energy and creativity: Modeling innovation diffusion, Structural Change and Economic Dynamics 13, 415-33.

Mahmud, Syed (2000) The energy demand in the manufacturing sector of Pakistan: Some further results, Energy Economics 22, 641-48.

Moroney, John (1992) Energy, capital and technological change in the Unites States, Resources and Energy, 363-80.

Pintus, Patrick (2006) Indeterminacy with almost constant returns to scale: Capital-labor substitution matters, Economic Theory 28, 633-649.

Raurich, Xavier, Hector Sala, and Valeri Sorolla (2012) Factor shares, the price markup, and the elasticity of substitution between capital and labor, Journal of Macroeconomics 34, 18198.

Takayama, Akira (1993) Analytical Methods in Economics, University of Michigan Press, Ann Arbor.

Thompson, Henry (2006) The applied theory of energy substitution in production, Energy Economics, 410-25.

Urga, Giovanni and Chris Walters (2003) Dynamic translog and linear logit models: A factor demand analysis of interfuel substitution in US industrial energy demand, Energy Economics 25, 1-21. 
THOMPSON Trends in Factor Price Elasticities

van der Werf, Edwin (2008) Production functions for climate modeling: An empirical analysis, Energy Economics 30, 2964-79. 